\title{
Resenha
}

\section{A contribuição da mídia para o desenvolvimento sustentável: o caso dos pescadores da Catalunha, Espanha, e de Corumbá, Brasil}

The media's contribution to sustainable development: the fishers in Catalonia, Spain, and Corumbá, Brasil.

GeRSON LUIZ MARTINS

Professor do Programa de Pós-Graduação em Comunicação da Universidade Federal do Mato Grosso do Sul - PPGCOM/UFMS.

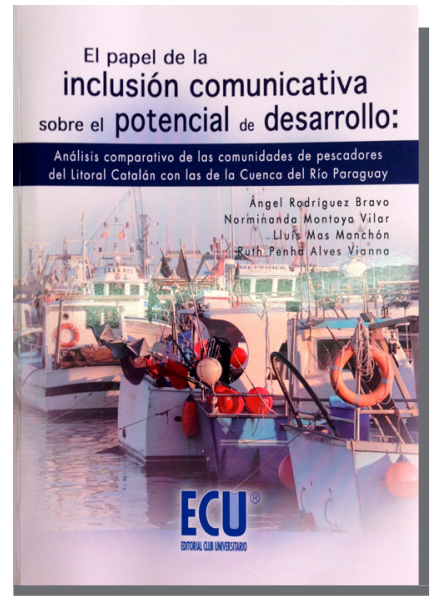

RODRIGUEZ BRAVO, Ángel; MONTOYA VILAR, Norminanda; MAS MANCHÓN, Lluís e VIANNA, Ruth Penha Alves.

El papel de la inclusión comunicativa sobre el potencial de desarollo: análisis comparativo de las comunidades de pescadores del Litoral Catalán con las de la Cuenca del Río Paraguay.

Alicante: Editorial Club Universitario, 2012. 210p.

$O_{\text {Bar }}$ texto produzido pelos professores da Universidade Autônoma de Barcelona é resultado do projeto de pesquisa realizado na Catalunha, especificamente, na cidade de Vilanova i La Geltrú e, no Brasil, na cidade de Corumbá, Mato Grosso do Sul. O trabalho faz uma importante reflexão 
sobre as contribuições da mídia, em geral, no desenvolvimento das comunidades de pescadores nas duas regiões. Os autores partiram da experiência e convivência com os dois grupos de pescadores, diante da importância que essas comunidades têm para o desenvolvimento local, como duas áreas que têm na pesca seu principal recurso econômico. Aliado a este fato, um fator se mostrou relevante para a pesquisa, qual seja, a escassez do produto e a extinção dessa atividade econômica.

Os autores consideram os dois ambientes distintos: no primeiro, a economia é de pesca marinha, e, no segundo, de pesca de rio. Também consideram, na pesquisa e no texto produzido, as diferenças do desenvolvimento social, político, tecnológico e econômico das duas comunidades. $\mathrm{O}$ texto fundamenta, nas primeiras páginas, a escolha e os modelos metodológicos utilizados para validar o estudo comparativo. Levanta algumas hipóteses que, no final do estudo, são comprovadas, em sua maioria, apesar das diferenças apontadas anteriormente. Essa "comprobabilidade" das hipóteses ocorre em consequência de um modelo metodológico minuciosamente pensado e trabalhado.

Esse tratamento metodológico, para além do conteúdo pesquisado, faz a riqueza do texto, considerando que os locos de pesquisa são muito diferentes e, portanto, a princípio, sem validade para uma pesquisa comparativa. Importante destacar esse procedimento dos autores, que afirmam que, para desenvolver com solidez metodológica este tipo de estudo, os âmbitos sociais que se comparam devem satisfazer as seguintes condições: (1) estarem localizados em áreas geográficas suficientemente distantes para assegurar que não haja nenhuma contaminação entre eles; (2) serem constituídos em núcleos sociais semelhantes em tamanho de população e de atividade produtiva; (3) terem acesso à mídia, recursos e infraestrutura de comunicação muito diferentes, sendo capazes de demonstrar uma clara e documentada dúvida de que a primeira é incorporada em um campo comunicativo desenvolvido, e, a segunda, em 
um ambiente com um grau imediato de desenvolvimento precário; (4) possuírem problemas semelhantes de desadaptação à evolução recente de seus ambientes, que afetem seriamente a sua sobrevivência e obriguem a assumir mudanças profundas em suas vidas produtiva, econômica e social (Rodriguez Bravo et al., 2012, p. 22).

Os autores escolhem o método de estudo de caso como o procedimento metodológico mais adequado para desenvolver o plano de trabalho e cumprir com os objetivos da pesquisa. Esta escolha está fundamentada nos estudos de Martínez Carazo (2006) que destaca

Em um procedimento metodológico deste tipo, geralmente ser necessário trabalhar com múltiplas fontes de dados, seu ponto de partida é o levantamento das perguntas de pesquisa e o núcleo central de sua prestação de contas metodológica é a confrontação destas fontes (triangulação) em busca de seus elementos comuns e de suas contradições."

(Rodriguez Bravo et al., 2012. p. 26)

O objetivo do estudo está claramente definido no sentido de pesquisar, desde a perspectiva estrita do receptor, representado pelas duas comunidades escolhidas, qual é o grau de contribuição real que realizam as infraestruturas e os meios de comunicação aos seus usuários, à comunidade receptiva, para ajudá-los na sobrevivência diária e na adaptação às mudanças do local em que vivem, e, também, para superar a crise de sua atividade principal, o pescado, nas mudanças que se realizam conforme as diretrizes políticas e econômicas, que são definidas pelos governos. Assim, Rodriguez Bravo et al. $(2012$, p. 20) destaca que a pesquisa está focalizada em explorar se existem conexões reais entre o fenômeno da disponibilidade dos meios de comunicação e a inclusão/ 
exclusão comunicativa, com a capacidade de desenvolvimento das comunidades incluídas ou excluídas. Também, em interpretar a capacidade para o desenvolvimento de uma comunidade com sua habilidade e disposição para a adaptação às mudanças do entorno social, que influem de forma direta na sua vida cotidiana.

O texto faz uma detalhada revisão histórica e geográfica das duas localidades de pesquisa, enfatiza as diferenças no grau de desenvolvimento tecnológico e, principalmente, na disponibilidade e acessibilidade midiática para as duas comunidades. Destaca que apesar das grandes diferenças nesses aspectos, os problemas enfrentados pelas duas comunidades e a influência ou contribuição dos meios de comunicação não são muito diferentes. Dessa forma, Rodriguez Bravo et al. apontam similitudes que validam o estudo comparativo. Como ambas as comunidades profissionais estão localizadas em entornos cujos ecossistemas estão submetidos a um deterioramento ecológico progressivo, ambas as comunidades profissionais carecem de uma cultura social e ecológica que favoreça comportamentos de educação ambiental. As duas comunidades foram forçadas, pela legislação, a reduzir o trabalho pesqueiro e, tanto na comunidade de Vilanova i La Geltrú, quanto Corumbá, os pescadores não têm controle sobre a comercialização do pescado.

Se do lado de Vilanova i La Geltrú os pescadores possuem alto índice de desenvolvimento na atividade pesqueira, com barcos providos de radar, diversos equipamentos eletrônicos - tanto de navegação quanto para pesca em si -, do outro lado, os pescadores de Corumbá realizam a atividade de forma artesanal e sem qualquer recurso eletrônico, que possa ampliar a produtividade. Ainda, se de um lado a comunidade pesqueira de Vilanova i La Geltrú tem ao seu dispor três emissoras de TV com sinal digital, seis emissoras de rádio e seis periódicos impressos, de outro lado, Corumbá possui um periódico impresso local, três sítios web de notícias, uma emissora de TV local e três emissoras de rádio - sem contar os meios de comunicação 
sediados nos centros regionais, como Barcelona, na Catalunha, e Campo Grande, em Mato Grosso do Sul, que também são acessíveis às duas comunidades. As perspectivas do estudo apontam para similaridade de acesso aos meios de comunicação e do papel que estes desempenham no desenvolvimento destas comunidades.

O resultado da pesquisa e objeto do texto em questão concluem, con claridad, que, no caso das comunidades pesquisadas, a disponibilidade das tecnologias da informação e da comunicação (TICs) e o acesso aos meios e infraestruturas de comunicação não mostram qualquer influência determinante sobre a capacidade de adaptação às diversidades do entorno econômico e social. E, para finalizar, Rodriguez Bravo et al (2012, p. 141) salienta que

O resultado desta investigação põe, pois, na questão da teoria da inclusão-exclusão comunicativa para o desenvolvimento dos povos e mostra que a inclusão real não depende somente da disponibilidade de infraestrutura midiáticas nem da "inclusão" informativa ou informática das comunidades, senão do conhecimento, uso e gestão adequada destes meios de comunicação."

É uma obra de qualidade, que contribui para compreender os procedimentos metodológicos nesse tipo de pesquisa, como também, importante no foco da pesquisa para os estudos de recepção.

\section{REFERÊNCIA}

MARTINEZ CARAZO, Piedad Cristina. El método de estúdio de caso. Estrategia metodológica de la investigación científica. Pensamento \& Gestión, 20. Barranquilla: Universidad del Norte, 2006. 